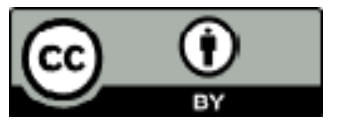

Domagoj Vidović

Institut za hrvatski jezik i jezikoslovlje
UDK 811.163.42'342.8

Pregledni članak

Prihvaćen za tisak 09.04.2020. https://doi.org/10.29162/jez.2020.1

\title{
Hrvatski naglasni sustav između deskriptivnoga i preskriptivnoga pristupa*
}

U radu se opisuju različiti sustavi naglašivanja s osobitim osvrtom na Školski rječnik hrvatskoga jezika i Hrvatski mrežni rječnik (Mrežnik). Posebno se problematiziraju četiri teme: 1) odnos priručnika prema standardnojezičnim naglasnim pravilima, 2) pitanje uporabne norme s posebnim osvrtom na naglasni inventar i dijalektnu sliku, 3) provedba načela normativne hijerarhije u naglasnoj normi te 4) primjeri obrade iz dvaju navedenih rječnika.

Ključne riječi: hrvatski standardni jezik; standardnojezična naglasna norma; deskriptivni pristup; preskriptivni pristup; mjesni govori.

\section{Uvod}

U radu se raščlanjuju različiti pristupi suvremenomu naglašivanju s osobitim osvrtom na Školski rječnik hrvatskoga jezika (Birtić i dr. 2012) i Hrvatski mrežni rječnik (Mrežnik). Rad čine četiri temeljne cjeline: 1) odnos priručnika prema standardnojezičnim naglasnim pravilima, 2) pitanje uporabne norme s posebnim osvrtom na naglasni inventar i dijalektnu sliku, 3) provedba načela normativne hijerarhije u naglasnoj normi i 4) primjeri obrade iz dvaju navedenih rječnika. U okviru prve cjeline ponajprije se osvrće na kategorije u kojima se od druge polovice 20 . stoljeća sustavno pojavljuju silazni naglasci u sredini riječi. U drugoj se naznačuju različiti pogledi na uporabnu normu s obzirom na naglasni inventar, naglasnu osnovicu hrvatskoga standardnog jezika i suvremenu hrvatsku dijalektnu sliku, u trećoj se nastoji prikazati kako bi mogla izgledati obrada kad bi se sustavno provelo načelo normativne hijerarhije usporedivo s teorijom o varijetetima koju naznačuju

\footnotetext{
* Rad je izrađen na istraživačkome projektu Hrvatski mrežni rječnik - MREŽNIK (IP-2016-062141), koji u cijelosti financira Hrvatska zaklada za znanost i koji se provodi u ustanovi nositelju projekta Institutu za hrvatski jezik i jezikoslovlje.
} 
drugi autori (npr. Martinović 2018), a u četvrtome primjeri iz navedenih dvaju rječnika. Kroz cjelokupan se rad preispituje odnos između deskriptivnoga i preskriptivnoga pristupa naglašivanju.

\section{Odnos priručnika prema standardnojezičnim naglasnim pravi- lima}

Od četiriju se temeljnih pravila o distribuciji naglasaka u priručnicima najčešće problematizira pravilo po kojemu se silazni naglasci ne ostvaruju u sredini i na kraju riječi. ${ }^{1}$ Međutim, odstupanja su od toga pravila zabilježena već na koncu 19. i početkom 20. stoljeća, a iznimke se od navedenoga naglasnog pravila navode u trećemu izdanju Gramatike hrvatskoga ili srpskoga književnog jezika (1963) Tome Maretića $^{2}$ te u Pravopisu hrvatskosrpskoga književnog jezika s pravopisnim priručnikom $\left(1960\right.$, npr. poljoprïvrednik $\left.{ }^{3}\right)$. U tim se priručnicima od navedenoga naglasnog pravila uglavnom odstupa u složenicama. Od 90-ih godina 20. stoljeća broj se kategorija u kojima se u sredini i na kraju riječi pojavljuju silazni naglasci povećao. Tako se u Hrvatskoj gramatici (Barić i dr. 1997: 70, 71) navodi kako se silazni naglasci na nepočetnome slogu pojavljuju u složenicama (primjerice, brodovlâsnīk), posuđenicama (primjerice, informâtor), stranim vlastitim imenima (primjerice, Montevidëo, Voltêr), u genitivu množine riječi s nepostojanim $a$ i s uzlaznim naglascima u ostalim padežima (primjerice, iskîstāvā) te u pokratama koje se izgovaraju nazivima početnih slova (primjerice, esade). Pritom se dodaje kako se „riječi s tak-

\footnotetext{
${ }^{1}$ Slično je i u ostalim južnoslavenskim standardnim jezicima utemeljenim na štokavskoj osnovici (za bošnjački jezik usp. Meco 2007). U priručnicima se navode i primjeri uzlaznih naglasaka u jednosložnim riječima i na zadnjemu slogu (usp. Maretić 1963: 133, Kapović 2015: 31). Većinom je riječ o uzvicima. Nadalje, ako se pretpostavku da ne postoji ni jedan hrvatski govor u kojemu se to pravilo ne provodi (a mnogi hrvatski govori navedeno pravilo vrlo dosljedno provode ili su ga provodili prije razdoblja znatnijega medijskog utjecaja na mjesne govore), može se postaviti pitanje postoji li ijedan hrvatski govor koji sadržava sve odrednice hrvatskoga standardnoga jezika. Naime, većina štokavskih govora ima drukčiji suglasnički sustav od hrvatskoga standardnog jezika, a na morfološkoj razini imperfekt je uščuvan u vrlo rijetkim primjerima. Ipak se, barem zasad, ne mijenja glasovni sustav hrvatskoga standardnog jezika niti se imperfekt izostavlja iz normativnih priručnika.

${ }^{2}$ Maretić (1963: 133) navodi da su iznimke od toga pravila „neke složene riječi u kojima narod meće akcent na drugi dio riječi, a prvi dio ostavlja bez akcent", među njima i riječi očiglëdnī, svojevöljno. Domeće da takvih naglasaka ima u narodnim govorima, ali i da „u književnom jeziku nisu uvijek takvi“".

${ }^{3}$ U pravopisu su razvidne hrvatsko-srpske razlike na svim jezičnim razinama, uključujući i naglasne, a primjeri kao što je poljoprïvrednik nemaju dodatnih normativnih uputa ni komentara.
} 


\section{EZIKOSLOVLJE \\ 21.1 (2020): 7-25}

vom raspodjelom naglasaka silaznih naglasaka mogu prihvatiti kao naglasne dublete (ponekad i triplete) ${ }^{\text {“4 }}$ te kako su u tim slučajevima silazni naglasci običniji od onih u skladu sa „sustavnom naglasnom normom“. U Gramatici hrvatskoga jezika (Silić i Pranjković 2007: 20) navode: „U klasičnome hrvatskom jeziku na zadnjemu slogu nema naglaska. U nekim se područjima zapadnoštokavskih govora, koji su u osnovici hrvatskoga standardnog jezika, pojavljuju silazni naglasci i na neprvome, pa onda i na zadnjemu slogu. Usp. organizâtor, relïkt, defëkt, subjëkt, kontinënt ${ }^{5}$ itd.“ U pravogovornome priručniku Naglasak u hrvatskome književnom jeziku. (Vukušić i dr. 2007: 49) razlikuju dvije kategorije silaznih naglasaka na nepočetnome slogu. Za prvu skupinu utvrđuju kako „kratkosilazni kao i dugosilazni mogu biti i na nepočetnome slogu, posebno u imenima i stranim riječima: dirigënt, $p a$ limpsëst, poluröđāk, poljoprïvrednik, prvobrätučed, ranoränilac, no to je rubno za cjelinu sustava, susreće se u razgovornom stilu, pa stoga nije potrebno stvarati nove uzorke.“ Kao primjere slične rubne pojave u tome se priručniku (Vukušić i dr. 2007: 88) navode i složenice ženskoga roda kao što su kupoprödaja ili samoöbma$n a$ te zemljopisna imena (i strana i domaća) kao što su Austrâlija, Melanêzija ili Premantûra. ${ }^{6}$ Normativni status tih riječi nije posve razvidan jer za neke od njih (dirigënt, palimpsëst, poluröđāk, prvobrätučed, samoöbmana) u Kazalu riječi stoji oznaka da pripadaju razgovornomu stilu, a za ostale nema te oznake niti se navode mogući (drugi) standardnojezični likovi. U genitivu množine u imenica muškoga roda tipa Dalmatinac i srednjega roda tipa iskustvo u tome se priručniku dopušta naglasna tripleta Dalmatínācā, Dalmàtīnācā i Dalmatînācā odnosno iskústāvā, iskūstāvā i iskûstāva ${ }^{7}$

U priručnicima kao što su Naglasni priručnik standardnog hrvatskoga jezika (Klaić 2013) i Hrvatski jezični savjetnik (Barić i dr. 1999) te u Rječniku hrvatskoga jezika (RHJ) Leksikografskoga zavoda (Šonje 2000) nema odstupanja od standardnojezičnih naglasnih pravila.

Kad je riječ o suvremenim deskriptivnim hrvatskim rječnicima, u mnogima se od njih dopuštaju silazni naglasci, uglavnom u posuđenicama i najčešće nesustav-

\footnotetext{
${ }^{4}$ Kao primjer tripleta navode se usporedni primjeri hàrfistica, harfistica i harfistica. U Školskome rječniku i Mrě̌niku navodi se samo prvi lik.

${ }^{5}$ Kapović (2015: 31) bilježi kako su silazni naglasci na nepočetnome slogu uobičajeni i u usklicima (primjerice, ajôj) i u ekspresivnome izgovoru (primjerice, racionâlno).

${ }^{6}$ Pritom se ondje dopušta i metatonijski naglasak tipa Premantúra. U Barić i dr. (1999: 369) zabilježen je i metatonijski i sustavni naglasak (primjerice, Austrálija i Aùstrālija).

${ }^{7}$ U Barić i dr. (1999: 457, 623) su zabilježeni metatonijski i sustavni naglasak (Dalmatínācā i Dalmàtīnācā; iskústāvā i iskūstāvā), a odstupanja od standardnojezičnih naglasnih pravila nema.
} 
no. Primjerice, u Hrvatskome enciklopedijskom rječniku (Anić i dr. 2002) uz likove se asistent i organizātor nalaze i likovi asistënt ${ }^{8}$ i organizâtor, ${ }^{9}$ a u Anićevu rokokô uz rokòko.

U suvremenim se, dakle, jezičnim priručnicima uglavnom još primjenjuje četveronaglasna standardnojezična norma. Otkloni su od standardnojezičnoga naglašivanja zabilježeni u posuđenicama, složenicama, u stranih imena i rjeđe domaćih te u genitivu množine dijela imenica muškoga i srednjega roda. Otklona je više i češći su u deskriptivnim priručnicima. ${ }^{10}$ Ipak, u većini su slučajeva uz primjere sa silaznim naglaskom na nepočetnome slogu zabilježeni i naglasci u kojima se ne krše standardnojezična naglasna pravila. Budući da su standardnojezični naglasci u tim kategorijama ne samo sustavni, nego i ovjereni i potvrđeni u jezičnim priručnicima, njima se, po načelu normativne hijerarhije, u Školskome rječniku hrvatskoga jezika (Birtić i dr. 2012) i Mrežniku, kao normativnim priručnicima, daje prednost. ${ }^{11}$ Slično se postupilo i u genitivu množine muškoga roda tipa Dalmatinac i srednjega roda tipa iskustvo, u kojemu su navedeni isključivo sustavni, ovjereni i potvrđeni likovi Dalmàtīnācā odnosno iskūstāvā jer su likovi Dalmatínācā i iskústāvā, iako potvrđeni u priručnicima, dijalektno obilježeni, ${ }^{12}$ a likovi Dalmatînācā i iskûstāvea krše standardnojezična naglasna pravila. ${ }^{13}$

\footnotetext{
${ }^{8}$ Pritom se u navedenome rječniku bilježi samo lik stùdent. Benić (2007: 17-18) navodi kako se u nekim govorima naglasak povlači u dvosložnim, a ne povlači u višesložnim riječima (npr. stùdent, ali apsolvënt; žìrant, ali komandänt).

${ }^{9} \mathrm{U}$ istome je rječniku uz naglasak radijātor naveden i metatonijski radijátor, ali se donosi samo lik akumùlātor.

${ }^{10}$ Anićev rječnik i Hrvatski enciklopedijski rječnik sadržavaju znatno manje normativnih uputnica od RHJ-a te Školskoga rječnika i ne samo na naglasnoj, nego i na leksičkoj razini. Anićev rječnik znatno je otvoreniji posuđenicama, regionalizmima i dijalektizmima. Deskriptivne su pojedine suvremene gramatike poput Hrvatske gramatike Eugenije Barić i dr. u kojima različiti autori unutar iste knjige bilježe različite naglaske pojedinih riječi.

${ }^{11}$ Kako bi se održalo naglasno pravilo, u standardnojezičnim se rječnicima često zapisuju metatonijski naglasci ne samo u složenicama (primjerice, poljoprìvreda), nego i sustavno u genitivu jednine imenica ženskoga roda tipa rečènīca $\overline{\text {. }}$

${ }^{12}$ Riječ je o metatoniji svojstvenoj dijelovima Like i sjeverne Dalmacije (na području dodira čakavskih i štokavskih govora) te Slavonije (na području dodira novoštokavskih i staroštokavskih govora). Lik je Amerikánka (uz lik Amerikānka) potvrđen u Barić i dr. (1999: 55).

13 Anić (1998: 1409) napominje da se silazne naglaske na unutrašnjemu slogu genitiva množine (npr. Bosânācā) „može nazivati različitim terminima (podstandardnima ili razgovornima)“. Upravo su zbog dijalektne obilježenosti metatonijskih naglasaka (npr. Bosánācā) s jedne strane i kršenja standarnojezičnih naglasnih pravila s druge (npr. Bosânācā) izabrani likovi koji su ovjeren u priručnicima i potvrđeni u mjesnim govorima (npr. Bòsānācā).
} 


\section{Odnos norme i uporabe}

U nekima se od već spomenutih jezičnih priručnika na uporabnoj ili komunikacijskoj razini preispituje i uloga zanaglasne dužine. Tako se u Hrvatskoj gramatici (Barić i dr. 1997: 70) naznačuju: „U razgovornome jeziku zanaglasna dužina često izostaje.“ U Gramatici hrvatskoga jezika Josip Silić i Ivo Pranjković (2007: 20) navode: „Ovdje treba reći da je dužina činjenica strukture hrvatskoga jezika. I zato je treba pisati svugdje gdje to gramatika nalaže. Drugo je njezin status u komunikaciji. U komunikaciji se naime ona i izgovara i ne izgovara." I dok se u spomenutim dvjema gramatikama gubljenje zanaglasne dužine navodi kao značajka razgovornoga stila, koji ne pripada hrvatskomu standardnom jeziku, te se ne navode kategorije u kojima bi se ona mogla izostaviti, u Rječniku hrvatskoga jezika Vladimir Anić (1994: VII) navodi kako zanaglasnu dužinu ne bilježi ,na posljednjemu slogu u 1. licu prezenta glagola na -irati“ te u ,riječima kao prävopis (ne prävopiss)“. ${ }^{14}$

U pojedinim je, pak, radovima otklon od standardnojezične norme na distribucijskoj razini još izraženiji. Od 70-ih godina 20. stoljeća počeo se u kroatistici problematizirati naglasni inventar hrvatskoga standardnog jezika pokušajem uvođenja „tronaglasne uporabne norme“ (npr. Škarić 2006), a istodobno je iskazana potreba za uključivanjem u oblikovanje naglasne norme značajka govora velikih gradova (npr. Mićanović 2005). ${ }^{15}$

Jednim se dijelom zahvat u naglasnu normu opravdavao neravnopravnošću govornika kajkavskoga i čakavskoga narječja, no nije se uzimalo u obzir činjenicu da je naglasna norma samo jedna od norma te da navedena dva narječja osim na naglasnoj razini znatno odstupaju od hrvatskoga standardnog jezika i na fonološkoj, ${ }^{16}$ morfološkoj, sintaktičkoj i leksičkoj razini. ${ }^{17}$ Od druge polovice 20. stoljeća u kroa-

\footnotetext{
${ }^{14}$ Anić (1994: VII-VIII) kao sustavan zahvat navodi izostavljanje dužine iza dugouzlaznoga naglaska u prezentu glagola tipa pásem iako je riječ o sustavnome naglasku (usp. čak. pāsën) te je lik pásēm analoški. S druge strane, ostavlja analoški lik pèčèm iako je lik pèčem sustavan (usp. čak. pečën). Ujedno navodi kako se dužina gubi i u ,instrumentalu imenica na -ost (mlädosti/mlädošću)“. Kako je u instrumentalu imenica $i$-vrste naglasak kratak, ne može se govoriti o gubljenju dužine.

${ }^{15}$ Veći hrvatski gradovi imaju različit dijalektni supstrat (koji se na naglasnoj razini očituje u različitome naglasnom inventaru, ali i distribuciji naglasaka) i sociolingvističku strukturu (pitanje prestižnosti pojedinih govora) te ih je nemoguće promatrati skupno.

${ }^{16}$ U kajkavskome, primjerice, Mijo Lončarić (1994: 22) izdvaja 12 samoglasničkih sustava tvrdeći da ih je nekoć bilo i znatno više.

${ }^{17}$ Ako bi, pak, naglasna norma krenula u smjeru znatnijega uključivanja značajka drugih narječja, to bi trebalo provesti i na drugim jezičnim razinama, pa bi se moglo raspravljati o ukidanju vokativa ili futura I. te uvođenju supina ako hrvatski standardni jezik želimo približiti kajkavcima, uvođenju
} 
tistici je često u uporabi pojam tronarječna dijalektna osnovica (primjerice, Moguš 1993: 159) ili (novo)štokavska dijalektna osnovica s kajkavsko-čakavskoštokavskom nadgradnjom (primjerice, Frančić i dr. 2005: 23), pa iako se i taj pojam katkad problematizira (usp. Tafra 2011: 44, 45), razvidno je da je naglasna norma u svim suvremenim hrvatskim priručnicima, bez obzira na manje otklone, utemeljena na novoštokavskome naglasnom sustavu zapadnoga tipa. Izbor je dijalektne osnovice nužan jer je slika hrvatskoga jezika najsloženija na južnoslavenskome jezičnom prostoru jer su samo Hrvati čakavci, kajkavci i štokavci, a među njima ima i govornika torlačkoga dijalekta kojega dio dijalektologa (usp. Lisac 2003: 183) smatra posebnim narječjem. Kao što je jekavski izgovor izabran kao standardnojezični između triju glavnih izgovora jata (iako je ikavski izgovor najrasprostranjeniji ne samo među štokavcima, nego i čakavcima, a rubno i među kajkavcima), tako je i četveronaglasni naglasni sustav izabran između različitih naglasnih sustava u rasponu od dinamičkoga do peteronaglasnoga. Uostalom, udio je govornika štokavskoga narječja među govornicima hrvatskoga jezika danas znatno veći nego u 17. stoljeću kad je štokavsko narječje preuzelo primat u oblikovanju hrvatskoga književnog jezika ili u prvoj polovici 19. stoljeća kad se počeo oblikovati suvremeni hrvatski standardni jezik.

Sliku o naglasnome inventaru hrvatskih govornika na temelju koje se nastoji oblikovati uporabna norma, a koja je utemeljena na ispitivanju s pomoću anketa opovrgavaju dijalektološka istraživanja. ${ }^{18}$ Naime, po nekim je podatcima među govornicima hrvatskoga jezika u Hrvatskoj 57\% štokavaca, 31\% kajkavaca i 12\% čaka-

predbudućega vremena i kondicionala tvorenoga od arhaičnoga oblika glagola biti (bin - biš) ako hrvatski standardni jezik želimo približiti čakavcima, uvođenju razlikovanja množinskih padeža u imenica ako hrvatski standardni jezik želimo približiti dijelu kajkavaca i čakavaca ili svođenju dvaju parova slivenika na jedan ako ga želimo približiti kajkavskim te dijelu čakavskih i štokavskih govora. Razlike je na leksičkoj razini suvišno i spominjati.

${ }^{18}$ O upitnim je metodološkim postupcima u anketama Ive Škarića pisao Mate Kapović (2007: 75), a općenito bi u njih, osim većega broja ispitanika (u većini se anketira tek nekoliko desetaka govornika hrvatskoga jezika) trebalo uključiti podatke o podrijetlu ispitanika i njihovim polaznim idiomima kako bismo vidjeli koliko su uravnotežene te povećati broj ispitanika. Čak i u uravnoteženim istraživanjima poput onoga koje je provela Elenmari Pletikos (2008) razvidna je nerazmjerna zastupljenost govornika hrvatskoga jezika. Primjerice, u njezinu istraživanju nije zastupljen nijedan govornik hrvatskoga jezika iz Like i Dalmatinske zagore, a općenito su izrazito podzastupljeni ispitanici iz najmnogoljudnijih dalmatinskih županija, Zadarske i Splitsko-dalmatinske (štoviše, nema nijednoga ispitanika iz Zadra). Nadalje, Dubrovačko-neretvanska županija označena je isključivo kao štokavska, a jedan je od triju ispitanika iz čakavske Vele Luke (Pletikos 2008: 83, 247). 


\section{EZIKOSLOVLJE \\ $21.1(2020): 7-25$}

vaca. ${ }^{19} \mathrm{Ti}$ se podatci, naravno, mogu problematizirati jer je, poglavito u većim gradovima te u ostalim pokrajinskim i područnim središtima u krajevima sa složenom dijalektnom strukturom teško odrediti kojemu narječju pripada neki mjesni govor, a ujedno je teško odrediti značajke svojstvene isključivo jednomu narječju. ${ }^{20} \mathrm{U}$ pogledu naglasnoga inventara u hrvatskim govorima najrelevantniji su radovi Mate Kapovića (Kapović 2015).

Iz zemljovida prikazanoga na slici 1 razvidno je kako su u Hrvatskoj prostorno najrašireniji govori s četveronaglasnim novoštokavskim inventarom, a u Bosni i Hercegovini nema nijednoga govora koji ima manje od četiriju naglasaka. Pritom se često iznose tvrdnje kako govornici s tim naglasnim sustavom ne nastanjuju velike hrvatske gradove, no podatci o mjestu i državi rođenja stanovnika Republike Hrvatske ujedno mogu donekle olakšati stvaranje slike o polazišnim naglasnim sustavima stanovnika većih hrvatskih gradova. Navest ću primjer hrvatskoga glavnog grada Zagreba u kojemu, po popisu stanovništva iz 2011. godine, ${ }^{21}$ živi 363148 (45,97\%) ljudi rođenih izvan grada u kojemu žive, među kojima je 98579 $(12,48 \%)$ ljudi rođenih u Bosni i Hercegovini, ${ }^{22}$ dakle ljudi koji nedvojbeno potječu iz štokavskoga područja. Među ostalih je 264569 Zagrepčana rođenih izvan grada u kojemu živi znatan udio doseljenika iz štokavskih krajeva unutar same Hrvatske (od Slavonije preko Banovine, Korduna i Like do Dalmacije) te je i stoga razvidno da se u potragu ,za kompetentnim govornikom“, kad je riječ o tzv. klasičnoj normi, može krenuti i iz Zagreba. ${ }^{23}$

${ }^{19}$ Usp. https://hr.wikipedia.org/wiki/\%C4\%8Cakavsko_narje\%C4\%8Dje i https://hr.wikipedia.org/wiki/Kajkavsko_narje\%C4\%8Dje. Datum posjeta stranici: 10. siječnja 2020.

${ }^{20}$ U Splitu se, primjerice, čakavski govor povlači već gotovo stoljeće, a ubrzano nakon Drugoga svjetskog rata te je danas u njemu, pogotovo u rubnim dijelovima grada, uz Splićane koji govore prepoznatljivom splitskom melodijom (koja je nastala zbog čakavsko-štokavskih dodira) velik udio govornika štokavskih ikavskih govora. O stupnju je čakavskosti pojedinih govora pisao još Milan Moguš u monografiji Čakavsko narječje (1977) te se ona određuje na svim jezičnim razinama, a već je prije sedamdesetak godina naglasni sustav čakavskih kopnenih govora u Dalmaciji bio pod snažnim štokavskim utjecajem.

${ }^{21}$ Podatci su navedeni prema

https://www.dzs.hr/hrv/censuses/census2011/results/htm/h01_01_25/H01_01_25.html. Datum posjeta stranici: 15 . siječnja 2020.

${ }^{22}$ Jedan je dio Zagrepčana rođenih u Bosni i Hercegovini zacijelo došao u Zagreb u ranome djetinjstvu, pa i to treba uzeti u obzir.

${ }^{23} \mathrm{Da}$, primjerice, Hrvati rođeni u Bosni i Hercegovini, vladaju novoštokavskim naglasnim sustavom sasvim je razvidno iz javnih nastupa pojedinih hrvatskih nogometaša iz kojih se vidi da se mogu služiti jednim od zagrebačkih idioma, ali i da im je posve prirodno izražavanje četveronaglasnim 


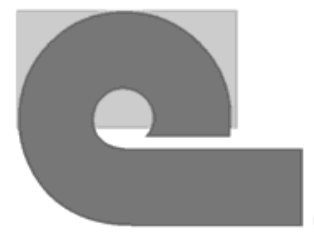

\section{Domagoj Vidović: \\ Hrvatski naglasni sustav između deskriptivnoga i preskriptivnoga pristupa}

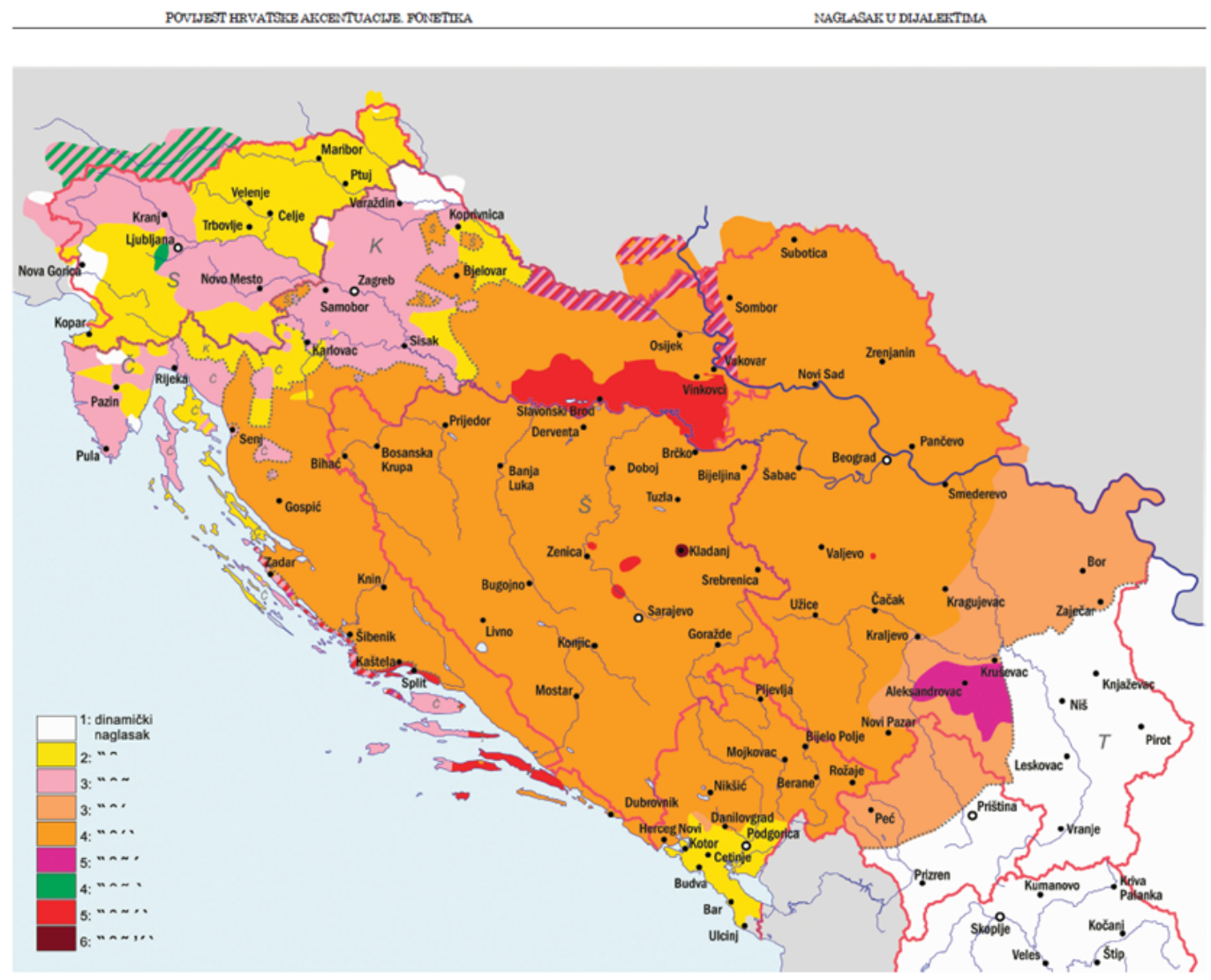

Broj naglasaka u dijalektima

50

Slika 1. Naglasni inventar u zapadnim i središnjim južnoslavenskim jezicima (iz Kapović 2015: 51)

Kad je riječ o suvremenome naglašivanju, Blaženka Martinović (2018: 125) izdvaja tri tendencije: „1) labaviji pristup distribucijskim pravilima u određenih kategorija riječi, 2) previranja u tvorbi riječi i neutralizacija likova s pomaknutim, čelnim naglaskom, 3) ujednaka naglasne paradigme i pretakanje jedinica iz tipa u tip“. Moguću bi uporabnu normu trebalo i podrobno opisati te jednoznačno odrediti tko

novoštokavskim sustavom. U zagrebačkim četvrtma Malešnici i Dubravi, u kojima žive velike skupine doseljenika sa štokavskoga područa, velik je udio Zagrepčana koji govore isključivo štokavski. Služenje barem dvama idiomima posve je uobičajeno u velikome dijelu hrvatskih krajeva već više stoljeća, poglavito ako govor grada ima različitu narječnu osnovicu od govora njegove okolice (govor se okolice uvijek donekle prilagođava gradskim govorima), ali i kad se u gradove nastane doseljenici iz krajeva s različitom dijalektnom osnovicom. 


\section{EZIKOSLOVLJE \\ 21.1 (2020): 7-25}

je kvalificiran da je oblikuje (svi govornici hrvatskoga jezika ili neka ciljna skupina govornika koji su po nekim kriterijima predodređeni kao kompetentni govornici) jer o tome ovisi i metodološki okvir. ${ }^{24}$ Naime, ako su za oblikovanje uporabne norme kvalificirani svi govornici hrvatskoga jezika, ono se ne može provesti bez dijalektoloških i povijesnojezičnih podataka. Otklon se od standardnojezične norme opisuje razlikovno u odnosu na trenutačnu naglasnu normu te ga se, budući da mu u nekim radovima nije određen ni inventar, ne može jednoznačno opisati, ali se često pretpostavlja već opisanoj naglasnoj normi te bi ga se stoga također moglo nazvati i preskriptivnim. Jedna je od kritika koju deskriptivisti najčešće upućuju preskriptivistima to da ,preskriptivisti u jeziku nameću arbitrarne stavove insistirajući na uporabi onih oblika koje oni osobno preferiraju“ (Mihaljević 2017: 386). Pritom se počesto prenaglašava mogući utjecaj jezikoslovaca sklonijih klasičnoj normi, za koje se katkad tvrdi da se zalažu za naglasne oblike koje sami ne izgovaraju, a podcjenjuje se uloga jezika medija, ${ }^{25}$ na čije su oblikovanje, barem kad je riječ o HRT-u, uvelike utjecale različite službe te savjeti za jezik i govor. Likovi köšarkaškī, rekreîrā ili izvještâvā koje izgovaraju novinari podrijetlom iz Makarskoga primorja, Imotske krajine, Konavala ili Hercegovine teško su mogli nastati spontano, a da i jesu, novinar bi, da je upozoren kako mjesni izgovor košàrkāǎš rekrèirāa ili izvjēštāvā odgovara standardnojezičnomu, jamačno aktivirao vlastite jezične kompetencije. Uostalom, poimanje je tzv. neutralnoga varijeteta, zbog iznimne hrvatske dijalektne raznolikosti, ${ }^{26}$ vrlo raznoliko među govornicima hrvatskoga jezika, počesto ovisi o osobnome dojmu, pa se izgovor zanaglasne dužine kajkavcu može činiti dijalektnom značajkom jer je nema u svojemu naglasnom inventaru, a štokavca izostanak zanaglasne dužine često upućuje na neštokavsko podrijetlo njegova sugovornika. S druge strane, gubljenje samoglasnika $i$ štokavcu iz dalmatinskoga zaleđa ili Hercegovine nije toliko izrazito obilježeno koliko čakavcu ili kajkavcu, pa ga i govornik iz toga područja ne doživljava toliko dijalektnim koliko se doživljava čakavski ili kajkavski vokalizam. S gledišta su standardnojezične norme i izostavljanje dužine i gubljenje samoglasnika $i$ dijalektne značajke te ne pripadaju hrvatskomu standardnom jeziku neovisno o dojmu ili preferenciji pojedi-

\footnotetext{
${ }^{24} \mathrm{O}$ problemu određivanja kompetentnoga govornika opširnije vidjeti u Martinović i Matešić 2018.

${ }^{25}$ O znatnoj ulozi medija govori i Ivo Pranjković (2009) navodeći kako se medijski centri nalaze izvan središnjega štokavskog područja te da je njihov utjecaj na izgovor sve veći.

${ }^{26}$ Tako Dalmatinci govor HRT-a doživljavaju zagrebačkim (usp. Runjić-Stoilova i Bartulović 2009: 163), a novoštokavski se izgovor na zagrebačkome i riječkome području doživljava ruralnim. Pranjković (2009), pak, navodi i da se dosljedno novoštokavsko naglašivanje počelo smatrati značajkom „regionalnoga, ruralnoga, pa možda čak (posebno posljednjih godina) i srpskoga tipa naglašavanja”.
} 
noga govornika hrvatskoga jezika jer su upravo dojam i preferencija, za razliku od sustava, proizvoljni. ${ }^{27}$

Kad je riječ o susjednim južnoslavenskim jezicima, treba napomenuti kako je četveronaglasna novoštokavska naglasna norma standardnojezična u bošnjačkome i srpskome jeziku, a u crnogorskome jeziku uz nju opstoji i dvonaglasna uporabna norma. Razlike su između srpskoga i hrvatskoga standardnojezičnoga naglašivanja razvidne već u djelima hrvatskih vukovaca te su uvjetovane najmanje trima čimbenicima: unutarnjim razlikama između istočne (pretežito srpske) i zapadne (pretežito hrvatske) štokavštine, znatno većom dijalektnom raznolikošću hrvatskoga jezika u odnosu na srpski te znatno „labavijim“ odnosom prema normi u srpskome jeziku nego u hrvatskome. Dijalektna je osnovica bošnjačkoga jezika najujednačenija jer je među Bošnjacima najveći udio novoštokavaca među južnoslavenskim narodima. Slovenski jezik dopušta dva naglasna sustava, tonski i netonski. Potonji je uveden u drugoj polovici 20. stoljeća s obrazloženjem da dvije trećine mjesnih govora nema tonski naglasak (usp. Kapović 2015: 85).

\section{Moguća provedba načela normativne hijerarhije u naglasnoj normi}

I unutar je četveronaglasnoga štokavskog sustava bilo nužno učiniti izbor jer se u jezičnim priručnicima s konca 19. stoljeća (npr. Akademijin rječnik i Maretićeva gramatika) donose različiti likovi potvrđeni u narodnim govorima te se s vremenom stvarala hrvatska standardnojezična naglasna norma. O različitim naglasnim mogućnostima i likovima, priređivači Klaićeva Velikoga rječnika (1974) navode: „Što se tiče akcenata, valja još reći da će se naći poneka razlika između akcenata pobilježenih u ovoj knjizi i i akcenata u shvaćanjima nekih naših akcentologa, no to je neizbježivo zbog širokog prostora našega jezičnog područja i zbog različitih izvora iz kojih su uzimani akcenti.“ Upravo je zbog množine različitih naglasnih likova potvrđenih među govornicima hrvatskoga jezika tada bilo (poglavito u posuđenicama koje u znatnoj mjeri do Klaićeva rječnika nisu bile naglašene), a danas je još potrebnije uspostaviti načelo normativne hijerarhije za čiju su provedbu, među ostalim, korisni i povijesnojezični te dijalektološki podatci. ${ }^{28}$ To je načelo usporedivo

\footnotetext{
${ }^{27}$ O doživljaju standarda u Zagrebu i Rijeci Mate Kapović (2004: 103) navodi: ,Jednonaglasni dinamični sustav Zagreba i Rijeke, s obzirom na to da ima ujednačeno povučeno mjesto naglaska (koje se nipošto ne podudara sa standardnim!) djeluje kao jezični uzor govornicima čakavskih i kajkavskih govora čiji naglasni sustavi radikalno odstupaju od standardnoga.“

${ }^{28}$ Ako je u čakavskim govorima sa starom akcentuacijom potvrđen lik čovïk, razvidno je da je obilno potvrđeni i sustavni naglasak čòvjek prikladniji za standardnojezičnu uporabu od lika čövjek po-
} 
s teorijom različitih naglasnih varijeteta (usp. Martinović 2018) te bi se moglo primijeniti u izradi budućih pravogovornih priručnika. Njime bi se, slično pravopisnim rješenjima, s pomoću načela normativne hijerarhije (usp. Birtić i dr. 2013: VIII) mogle uspostaviti preporučene (one koje imaju normativnu prednost), dopuštene (nemaju normativnu prednost, ali se zbog tradicije i čestoće uporabe ne isključuju) $\mathrm{i}$ istovrijedne inačice. Tim bi se sustavom mogao objasniti različiti normativni status pridjeva fillozofskī u odnosu prema filòzofskī i pèčem u odnosu prema pèčēm (budući da su u oba slučaja oba lika u skladu sa standardnojezičnim naglasnim pravilima, ovisno bi se o polazištu, jednomu od likova dala prednost ili bi se normativno izjednačili), ${ }^{29}$ normativno razradili naglasni likovi genitiva množine tipa Bòsānācā u odnosu prema likovima Bosánācā (metatonijski lik potvrđen u pojedinim govorima) i Bosânācā (koji jest ovjeren i u štokavskim govorima, ali odstupa od standardnojezičnih naglasnih pravila). Ujedno bi se mogla uspostaviti i razlika između preporučenih ${ }^{30} \mathrm{i}$ dopuštenih inačica u lokativu jednine imenica ženskoga roda $i$-vrste (npr. pomični naglasak mladòsti i analoški mlädosti) ili genitivu množine imenica muškoga roda $a$-vrste (mlađi naglasak sïnōvā i stariji sinóvā). ${ }^{31}$

\section{Primjeri iz Školskoga rječnika hrvatskoga jezika i Hrvatskoga mrežnog rječnika}

Budući da su Školski rječnik hrvatskoga jezika (Birtić i dr. 2012) i Hrvatski mrežni rječnik normativni rječnici, u njima je primijenjen preskriptivni pristup uz strogu provedbu standardnojezičnih naglasnih distribucijskih pravila te se u obama rječnicima navode isključivo preporučene inačice. Dopuštene se inačice zbog načela jed-

tvrđenoga u nekim priručnicima poput Hrvatskoga enciklopedijskog rječnika. Dakle, lik je čòvjek ponajprije izabran zbog ovjerenosti i potvrđenosti u jezičnim priručnicima, a njegov je izbor dodatno osnažen dijalektološkim podatcima.

${ }^{29}$ U Školskome rječniku hrvatskoga jezika i Hrvatskome mrežnom rječniku dana je prednost liku filozofskī ponajprije zbog tradicijskoga načela, ali se ono ne bi provodilo da nije usklađeno s načelom ovjerenosti i potvrđenosti u uporabi. Isključivo je lik pèčem ovjeren u Hrvatskome jezičnom savjetniku (Barić i dr. 1999) i Praktičnoj hrvatskoj gramatici Dragutina Raguža (1997) te se pravilno izvodi od čakavskoga pečèm. Raguž, s druge strane, navodi isključivo lik püjem, Školski rječnik i Mrežnik pïjèm, a Hrvatski jezični savjetnik pïjem i pïjêm. Lik je pèčem izabran zbog načela ovjerenosti i potvrđenosti u uporabi te stoga što je uobičajeniji u zapadnoj štokavštini (Kapović 2018: 192, 205), a pijjêm zbog toga što je ovjereniji i potvrđeniji i u hrvatskim jezičnim priručnicima i u hrvatskim govorima.

${ }^{30}$ Dakako da se izbor preporučenih inačica u Školskome rječniku i Mrežniku može problematizirati, a na moguće se ujednake paradigma uputilo u Vidović 2014.

${ }^{31}$ To je načelo na primjeru imenica $o$-osnova naznačeno u Vidović 2014. 
nostavnosti i normativne hijerarhije ne navode u Školskome rječniku hrvatskoga je$z i k a$, a u Mrežniku se ne navode zbog ograničenja trajanja projekta. ${ }^{32}$ Načelo primijenjeno u Školskome rječniku hrvatskoga jezika primijenjeno je i u Prvome školskom pravopisu hrvatskoga jezika (Hudeček i dr. 2016) kao priručnicima namijenjenim ponajprije djeci. Budući da je obrada u Mrežniku znatno složenija i stoga što je projekt vremenski ograničen na četiri godine, rječnik nije dodatno opterećen dvostrukim rješenjima.

U Školskome rječniku hrvatskoga jezika obrađeno je oko 30000 natuknica, a u Mrě̌niku oko 5600 (s tim da je predviđeno 10 000). U Školskome rječniku uz obvezatni se genitiv jednine donose nominativ i genitiv množine (ako je množina realna). U Mrežniku se navodi cijela paradigma i to i za dugu i za kratku množinu (u većini se suvremenih hrvatskih priručnika kratka množina navodi samo u nominativu množine).

ŠR: ̀̀gra im. $\check{z} .<\mathrm{G}$ ìgrē, D ìgri, A ìgru; $m n$. N ïgre, G igárā

MR: ìgra igra im. ž. G ìgrē, D ìgri, A ìgru, L ìgri, I ìgrōm; $m n$. NA ìgre, G igárā, DLI ìgrama

ŠR: $\quad$ br̂k $i m . m .<\mathrm{G}$ br̂ka, L bŕku; $m n$. br̈kovi/br̂rci, G br̈kōvā/br̂̀nā $>$

MR: br̂k brk im. m. G br̂ka, D br̂ku, A br̂k, L bŕku, I br̂kom; $m n$. N br̈kovi/br̂ci, $\mathrm{G}$ br̈kōvā/br̂kā, DLI br̈kovima/br̂cima, A br̈kove/br̂ke

ŠR: $\quad$ mlàdōst $\mathrm{im} . \check{z} .<\mathrm{G}$ mlädosti, L mladòsti, I mlädošću/mlädosti>

MR: mlädōst mladost im. ž. GD mlädosti, A mlädōst, L mladòsti, I mlädošću/mlädosti

ŠR: $\quad$ sîn $i m . m .<\mathrm{G}$ sîna; $m n$. $\mathrm{N}$ sìnovi, $\mathrm{G}$ sìnōvā $>$

MR: sîn sin im. m. (GA sîna, DL sînu, V sîne, I sînom; mn. NV sìnovi, G sìnōvā, DLI sìnovima, A sìnove

\footnotetext{
32 To što se u rječniku navodi samo jedan naglašeni oblik ne znači da je svaki drugi proskribiran, nego da je odabran kao jedno od mogućih rješenja. Time se provodi načelo jezične gospodarnosti. Slično navodi i Anić (1998: 1409): „Onaj tko se služi Rječnikom nalazi zabilježen uobičajen standardni (književni) naglasak. Ipak, mora znati da se svi drugačiji naglasci ne smatraju u praktičnom životu jezika jednako dalekim ili nepravilnim prema strogo shvaćenom književnom naglasku.“ Osim toga, kad bi se dosljedno provodio deskriptivni pristup (pođemo li od pretpostavke da se standardnojezični naglasni likovi mogu birati samo u okviru štokavskoga narječja), morali bi se bilježiti i likovi s reduciranim zanaglasnim dužinama ili bez njih, što bi znatno povećalo broj naglasnih likova te rječnike pretvorilo u dijalektološke studije.
} 


\section{EZIKOSLOVLJE \\ $21.1(2020): 7-25$}

U Školskome se rječniku uza opisne pridjeve u neodređenome obliku donose genitiv jednine, određeni oblik muškoga roda, ženski i srednji rod neodređenoga pridjeva te komparativ u muškome rodu, ako je realan, i po potrebi superlativ. U Mrežniku se uvijek donose komparativ i superlativ, ako su realni, u nominativu i genitivu jednine. U Školskome rječniku hrvatskoga jezika i Mrežniku sustavno je odabrana naglasna paradigma $c^{33}$ kao standardnojezična u pridjevskoj sklonidbi (tip mlâd - mláda - mlâdo - mlâdi; srëtan - srètna - srëtno), potvrđena među govornicima svih triju hrvatskih narječja (usp. Kapović 2008: 203).

ŠR: $\quad$ zèlen prid. $<\mathrm{G} \quad$ zelèna; $o d r . \quad$ zèlen̄i, $\mathrm{G} \quad$ zèlenōg(a); ž. $\quad$ zelèna, $s$. zelèno; komp. zelènijī

MR: zèlen zelen prid. G zelèna; odr. zèlen̄i, G zèlenōg(a); ž. zelèna, $s$. zelèno; komp. zelènijī, G zelènijēg(a); sup. najzelènijīi, G najzelènijēg(a)

ŠR: blâg prid. $<\mathrm{G}$ blága; odr. blâgī, $\mathrm{G}$ blâgōg(a); ž. blága, s. blâgo; komp. bläžī >

MR: blâg blag prid. G blága; odr. blâgī, G blâgōg(a); ž. blága, s. blâgo; komp. bläžì, G bläžēg(a); sup. nâjblažī, G nâjblažēg(a)

ŠR: $\quad$ släb prid. $<\mathrm{G}$ slàba; $o d r$. slàbī, $\mathrm{G}$ slàbōg(a); ž. slàba, s. släbo/; komp. slàbijīi $>$

MR: släb slab prid. G slàba; odr. slàbī, G slàbōg(a); ž. slàba, s. släbo; komp. slàbijī, G slàbijēg(a); sup. najslàbijī, G najslàbijēg(a)

U Školskome se rječniku donosi prvo lice jednine i treće lice množine prezenta. Treće se lice jednine prezenta navodi kod glagola koji dolaze samo u trećemu licu i kod onih kod kojih su se u trećemu licu jednine dogodile neke fonološke ili naglasne promjene (kod tih se glagola navodi i prvo lice jednine i treće lice jednine). Zatim se navodi imperativ u 1 . licu jednine. U Školskome se rječniku navodi i aorist i u svršenih i nesvršenih glagola te se obvezno navodi prvo lice jednine, a treće se lice jednine navodi kad je fonološki ili naglasno bitno. U imperfektu se navodi prvo lice svih nesvršenih glagola. Obvezatno se navodi pridjev radni u muškome rodu osim za one glagolske pridjeve koji se upotrebljavaju samo u srednjemu rodu. Kad su morfološki ili naglasno relevantni, navode se i glagolski pridjevi u srednjemu i ženskome rodu te u množini muškoga roda. Kod prijelaznih se i nekih povratnih glagola u muškome rodu obvezatno navodi i pridjev trpni, a glagolski se prilozi sadašnji i prošli navode kad su fonološki razlikovni. U Mrežniku se donosi cjelokupan prezent, pridjevi radni i trpni u svim trima rodovima te glagolski pridjevi.

${ }^{33}$ U Barić i dr. (1999) uz većinu se pridjeva navodi ženski rod (npr. srëtan - srètna). 
ŠR: vûći gl. nesvrš. prijel./neprijel. <prez. 1. l. jd. vúčem, 3. l. mn. vúkū, imp. vúci, aor. vúkoh, imperf. vúcijāh, prid. $r$. $m$. vûkao, ž. vúkla, $s$. vûklo, $m n$. vûkli, prid. $t$. vùčen, pril. $s$. vúkūći>

MR: vûći vući gl. nesvršs. prijel./neprijel. prez. jd. 1. l. vúčem, 2. l. vúčeš, 3. $l$. vúče, $m n$. 1. l. vúčemo, 2. l. vúčete, 3. $l$. vúkū; imp. vúci; aor. vúkoh; prid. $r$. $m$. vûkao, ž. vúkla, $s$. vûklo; prid. $t$. $m$. vùčen, ž. vučèna, $s$. vučèno; pril. $s$. vúkūći

Zemljopisna imena, etnici i ktetici u Školskome rječniku donose se isključivo u kanonskome obliku. U Mrežniku se donosi cjelokupna paradigma za zemljopisno ime, etnike i ktetik te napomena u kojoj su sadržani dodatni podatci (navode se povijesni i dijalektni toponimi, etnici i ktetici te izvanjezični podatci na temelju kojih se katkad donose i kraći jezični savjeti). Pomicanje je naglaska fakultativno kad je oslabljeno, a sustavno se provodi kad je neoslabljeno. Naime, iako se u literaturi navodi kako je prenošenje naglaska na prednaglasnicu sve rjeđa pojava (usp. Vukušić i dr. 2007: 29), neoslabljeno je prenošenje (npr. ü goru, ù grād, ü zemlju, ì pêt) i danas očuvano u većini štokavskih i čakavskih te dijelu kajkavskih govora.

ŠR:

Bösna Bosánac Bòsānka bòsanskī

MR:

Bösna, G Bösnē, D Bösni, A Bösnu, L u Bösni / ù Bosni, I Bösnōm

Bosánac, GA Bosánca, DL Bosáncu, V Bòsānče, I Bosáncem; mn. NV Bosánci, G Bòsānācā, DLI Bosáncima, A Bosánce

Bòsānka, G Bòsānkē, DL Bòsānki, A Bòsānku, V Bòsānko, I Bòsānkōm; mn . NAV Bòsānke, G Bòsānkā/Bòsānkī, DLI Bòsānkama ${ }^{35}$

bòsanskī

\footnotetext{
${ }^{34}$ Izgovor ovisi o fonološkome sustavu i naglasnome inventaru pojedinih čakavskih govora, ali je preskakanje naglaska neupitno. Kapović (2015: 32) neoslabljeno pomicanje naziva preskakanjem, a oslabljeno prenošenjem naglaska.

${ }^{35}$ Povijesni su etnici Bošnjak i Bošnjakinja 90-ih godina 20. stoljeća postali etnonimima koji se odnose na većinu južnoslavenskih muslimana, ponajprije u Bosni i Hercegovini, ali i u Srbiji, Crnoj Gori, Kosovu i Makedoniji (gdje su autohtono stanovništvo) te Hrvatskoj, Sloveniji i drugdje u iseljeništvu. U hrvatskome i srpskome jeziku jezik se Bošnjakâ naziva bošnjačkim, a u bošnjačkome bosanskim.
} 


\section{Zaključak}

U ovome su radu opisani različiti sustavi naglašivanja s osobitim osvrtom na Školski rječnik hrvatskoga jezika i Hrvatski mrežni rječnik (Mrežnik). Posebno se problematizirao odnos priručnika prema standardnojezičnim naglasnim pravilima, pitanje uporabne norme s posebnim osvrtom na naglasni inventar i dijalektnu sliku te (moguća) provedba načela normativne hijerarhije u naglasnoj normi, a na koncu su doneseni i primjeri obrade iz dvaju navedenih rječnika.

Unutar obrade prve teme posebno se obradio otklon od standardnojezičnoga pravila po kojemu se silazni naglasci ne pojavljuju u sredini i na kraju riječi. Utvrđeno je da se u temeljnim jezičnim priručnicima silazni naglasci u sredini i na kraju riječi najčešće pojavljuju u složenicama, posuđenicama i u genitivu množine dijela imenica muškoga i srednjega roda, ali su se uz njih navodili i likovi u skladu sa standardnojezičnim naglasnim pravilima, uglavnom sustavni (npr. organizātor, kòmārācāa), a rjeđe i metatonijski (primjerice, dijalektni, ali ovjereni lik komárācāa te neovjereni, ali mogući poljoprivrednīk). U nekim su starijim jezičnim priručnicima (poput Pravopisnoga priručnika) u pojedinim složenicama zabilježeni isključivo primjeri sa silaznim naglascima u sredini riječi (primjerice, samoöbrana).

Na prijelazu iz 20. stoljeća u 21. stoljeće u pojedinim se radovima počeo preispitivati naglasni inventar. Tako se Ivo Škarić zalagao za tronaglasnu uporabnu normu, a objavljeni su i mnogi radovi u kojima se, bez uvida u dijalektološka istraživanja, nastojalo opisati stanje u hrvatskim govorima te dati prilog oblikovanju nove naglasne norme uglavnom metodom navođenja razlika u odnosu na „klasičnu“ normu, pri čemu katkad nije posve razvidan ni naglasni inventar koji bi „nova“ norma trebala imati. Sustavni je otklon od „klasične“ norme u priručnicima proveo isključivo Vladimir Anić ukidanjem zanaglasne dužine u pojedinim kategorijama. Iako se pitanje naglasnoga inventara i dijalektne osnovice danas katkad preispituje, zbog velike je raznolikosti između hrvatskih govora i narječja bilo nužno odabrati određenu osnovicu (kao što se na fonološkoj razini odabrala štokavska jekavska osnovica). To je osobito potrebno kad je riječ o naglasnome sustavu jer se naglasni inventar hrvatskih govora kreće u rasponu od dinamičkoga do peteronaglasnoga. $\mathrm{Za}$ promjenu je, pak, naglasne osnovice potreban opći dogovor kakav je postignut među slovenskim jezikoslovcima, no preduvjet su za njega i znatnije promjene $u$ organskim govorima. U hrvatskome su jeziku novoštokavski govori i danas najrasprostranjeniji. Ujedno bi se korjenite promjene morale provesti na svim jezičnim razinama, a ne samo na naglasnoj.

Deskriptivni se pristup naglašivanju, koji se primjenjivao još u 19. stoljeću ispisivanjem primjera iz različitih narodnih govora, počeo djelomično napuštati već u 
djelima hrvatskih vukovaca, isprva razlikovnom metodom, a zatim preskripitivnim pristupom isprva u pravopisnim i inim rječnicima, a poslije i u pravogovornim priručnicima. Ipak, zbog razlika su unutar pojedinih sličnih, ali ne posve istovjetnih naglasnih sustava ostala mnoga otvorena pitanja, pa bi se sustavom preporučenih, dopuštenih i istovrijednih inačica, usporedivim $\mathrm{s}$ teorijom naglasnih varijeteta, moglo uspostaviti načelo normativne hijerarhije u suvremenome naglašivanju, i to ne samo za kanonski oblik, čime bi se mogla urediti trenutačna naglasna previranja i dvostrukosti, ali i odrediti smjernice za budućnost.

Budući da su Školski rječnik hrvatskoga jezika i Mrežnik normativni rječnici, natuknice su naglašene prema standardnojezičnim pravilima. Obrada je u Mrežniku opsežnija stoga što e-rječnici nisu prostorno ograničeni, ali kako vremenski jesu, sustavna će primjena načela normativne hijerarhije biti primijenjena u nekome budućem rječniku.

\section{Literatura}

Anić, Vladimir. 1994. Rječnik hrvatskoga jezika. Zagreb: Novi Liber.

Anić, Vladimir. 1998. Rječnik hrvatskoga jezika. Zagreb: Novi Liber.

Anić, Vladimir; Brozović-Rončević, Dunja; Goldstein, Ivo; Jojić, Ljiljana; Matasović, Ranko; Pranjković, Ivo. 2002. Hrvatski enciklopedijski rječnik. Ur. Jojić, Ljiljana; Matasović, Ranko. Zagreb: Novi liber.

Barić, Eugenija; Lončarić, Mijo; Malić, Dragica; Pavešić, Slavko; Peti, Mirko; Zečević, Vesna; Znika, Marija. 1997. Hrvatska gramatika. Zagreb: Školska knjiga.

Barić, Eugenija; Hudeček, Lana; Koharović, Nebojša; Lončarić, Mijo; Lukenda, Marko; Mamić, Mile; Mihaljević, Milica; Šarić, Ljiljana; Švaćko, Vanja; Vukojević, Luka; Zečević, Vesna; Žagar, Matko. 1999. Hrvatski jezični savjetnik. Zagreb: Institut za hrvatski jezik i jezikoslovlje, Pergamena i Školske novine.

Benić, Mislav. 2007. Osnovni podaci o osječkoj akcentuaciji. Filologija 48. 1-28.

Birtić, Matea; Blagus Bartolec, Goranka; Hudeček, Lana; Jojić, Ljiljana; Kovačević, Barbara; Lewis, Kristian; Matas Ivanković, Ivana; Mihaljević, Milica; Miloš, Irena; Ramadanović, Ermina; Vidović, Domagoj, 2012. Školski rječnik hrvatskoga jezika. Zagreb: Školska knjiga - Institut za hrvatski jezik i jezikoslovlje.

Birtić, Matea; Blagus Bartolec, Goranka; Hudeček, Lana; Jozić, Željko; Kovačević, Barbara; Lewis, Kristian; Matas Ivanković, Ivana, Mihaljević, Lana; Milković, Alen; Ramadanović, Ermina; Stojanov, Tomislav, Štrkalj Despot, Kristina. 2013. Hrvatski pravopis. Institut za hrvatski jezik i jezikoslovlje. Zagreb.

Čakavsko narječje. Dostupno na:

https://hr.wikipedia.org/wiki/\%C4\%8Cakavsko_narje\%C4\%8Dje. Datum posjeta stra- 


\section{EZIKOSLOVLEE \\ $21.1(2020): 7-25$}

nici: 10. siječnja 2019.

Državni zavod za statistiku. Stanovništvo prema mjestu rođenja i spolu, popis 2011. Dostupno na: https://www.dzs.hr/hrv/censuses/census2011/results/htm/h01_01_25/H01_01_25.html. Datum posjeta stranici: 15. siječnja 2019.

Frančić, Anđela; Hudeček, Lana; Mihaljević, Milica. 2005. Normativnost $i$ višefunkcionalnost u hrvatskome standardnom jeziku. Zagreb: Hrvatska sveučilišna naklada.

Hudeček, Lana; Jozić, Željko; Lewis, Kristian; Mihaljević, Milica. 2016. Prvi školski pravopis hrvatskoga jezika. Zagreb: Institut za hrvatski jezik i jezikoslovlje.

Kapović, Mate. 2004. Jezični utjecaj velikih gradova. Rasprave Instituta za hrvatski jezik $i$ jezikoslovlje 30. 97-105.

Kapović, Mate. 2007. Hrvatski standard - evolucija ili revolucija? Problem hrvatskoga pravopisa i pravogovora. Jezikoslovlje 8(1). 61-76.

Kapović, Mate. 2008. Ustrojstvo rječničkoga članka u dijalekatnim rječnicima s obzirom na naglasak. Hrvatski dijalektološki zbornik 14. 197-205.

Kapović, Mate. 2015. Povijest hrvatske akcentuacije. Zagreb: Matica hrvatska.

Kapović, Mate. 2018. Povijest glagolske akcentuacije u štokavskom (i šire). Rasprave: časopis Instituta za hrvatski jezik i jezikoslovlje 44(1). 159-285.

Klaić, Bratoljub. 1974. Veliki rječnik stranih riječi, izraza i kratica. Zagreb: Zora.

Klaić, Bratoljub. 2013. Naglasni sustav standardnoga hrvatskog jezika. Zagreb: Nova knjiga Rast.

Lisac, Josip. 2003. Hrvatska dijalektologija 1., Hrvatski dijalekti i govori štokavskog narječja i hrvatski govori torlačkog narječja. Zagreb: Golden marketing - Tehnička knjiga.

Lončarić, Mijo. 1994. Kajkavski vokalizam. Rasprave Instituta za hrvatski jezik i jezikoslovlje 20(1). 115-135.

Maretić, Tomo. 1963. Gramatika hrvatskoga ili srpskoga jezika. Zagreb: Matica hrvatska.

Martinović, Blaženka. 2018. Naglasna norma neutralnoga varijeteta suvremenoga hrvatskog jezika. U Mlikota, Jadranka (ur.), Od norme do uporabe 1, 123-139. Osijek: Filozofski fakultet Sveučilišta Josipa Jurja Strossmayera u Osijeku - Hrvatska sveučilišna naklada.

Martinović, Blaženka; Matešić, Mihaela. 2018. U potrazi za kompetentnim govornikom. Zbornik radova Filozofskog fakulteta u Splitu 11. 153-168.

Meco, Zenaida. 2007. Silazni naglasci u bosanskom jeziku - norma i stvarno stanje. Bečanović, Tatjana (ur.), Zbornik radova sa međunarodnog slavističkog naučnog skupa Njegoševi dani 1, 61-76. Nikšić: Univerzitet Crne Gore - Filozofski fakultet.

Mićanović, Krešimir. 2005. Hrvatski s naglaskom. U Pranjković, Ivo (ur.), Od fonetike do etike. Zbornik o sedamdesetogodišnjici Josipa Silića, 387-393. Zagreb: Disput.

Mihaljević, Milica. 2017. Terminologija kao deskriptivna ili preskriptivna znanost - stanje u Hrvatskoj. U Piper, Predrag; Jovanović, Vladan (ur.), 383-403. Slovenska terminolo- 
gija danas. Beograd: SANU - Institut za srpski jezik SANU-a.

Moguš, Milan. 1977. Čakavsko narječje. Zagreb: Školska knjiga.

Moguš, Milan. 1993. Povijest hrvatskoga književnog jezika. Zagreb: Nakladni zavod Globus.

Pletikos, Elenamari. 2008. Akustički opis hrvatske prozodije riječi (Prozodija riječi u suvremenom općem naddijalektalnom govoru). Neobjavljena doktorska disertacija, Zagreb: Filozofski fakultet Sveučilišta u Zagreb.

Pranjković, Ivo. 2009. Za demokratizaciju hrvatske ortoepske norme. Anagram. Dostupno na: http://www.hrvatskiplus.org/article.php?id=1825\&naslov=za-demokratizacijuhrvatske-ortoepske-norme. Datum posjeta stranici 10. ožujka 2019.

Pravopis hrvatskosrpskoga književnog jezika s pravopisnim priručnikom. 1960. Zagreb Novi Sad: Matica hrvatska - Matica srpska.

Raguž, Dragutin. 1997. Praktična hrvatska gramatika. Zagreb: Medicinska naklada.

Runjić-Stoilova, Anita; Bartulović, Ivana. 2009. Odstupanja od standardnog naglasnog sustava u govoru profesionalnih govornika na HTV-u. Zbornik radova Filozofskog fakulteta u Splitu 2. 153-158.

Silić, Josip; Pranjković, Ivo. 2007. Gramatika hrvatskoga jezika za gimnazije i visoka učilišta. Zagreb: Školska knjiga.

Škarić, Ivo. 2006. Hrvatski govorili! Zagreb: Školska knjiga.

Šonje, Jure (gl. ur.). 2000. Rječnik hrvatskoga jezika. Zagreb: Leksikografski zavod Miroslav Krleža - Školska knjiga.

Tafra, Branka. 2011. Kroatistička standardološka ispitivanja. U Sesar, Dubravka (ur.), Slavenski jezici u usporedbi s hrvatskim II, 35-49. Zagreb: FF press.

Vidović, Domagoj. 2014. Naglasci u Rječniku stranih riječi i naglasnome priručniku Adolfa Bratoljuba Klaića u usporedbi sa Školskim rječnikom hrvatskoga jezika. Rasprave: časopis Instituta za hrvatski jezik i jezikoslovlje 40(2). 497-520.

Vukušić, Stjepan; Zoričić, Ivan; Grasseli-Vukušić, Marija. 2007. Naglasak u hrvatskome književnom jeziku. Zagreb: Nakladni zavod Globus.

\section{Adresa autora:}

Institut za hrvatski jezik i jezikoslovlje

Ulica Republike Austrije 16, Zagreb

E-mail: dvidovic@ihjj.hr 


\section{CROATIAN ACCENTUATION SYSTEM}

\section{BETWEEN THE DESCRIPTIVE AND THE PRESCRIPTIVE APPROACH}

The paper describes different systems of accentuation with a special emphasis on two dictionaries, viz. Školski rječnik hrvatskoga jezika and Hrvatski mrežni rječnik - Mrežnik. It focuses on four issues: 1 . the approach to accentuation rules of the standard language in language manuals, 2 . the question of the usage norm with an overview on the inventory of accents and the dialectological picture, 3. the normative hierarchy in the accentuation norm, and 4. examples of accentuated forms from these two dictionaries.

Key words: Croatian standard language; accentological norm of the standard language; descriptive approach; prescriptive approach; dialects. 